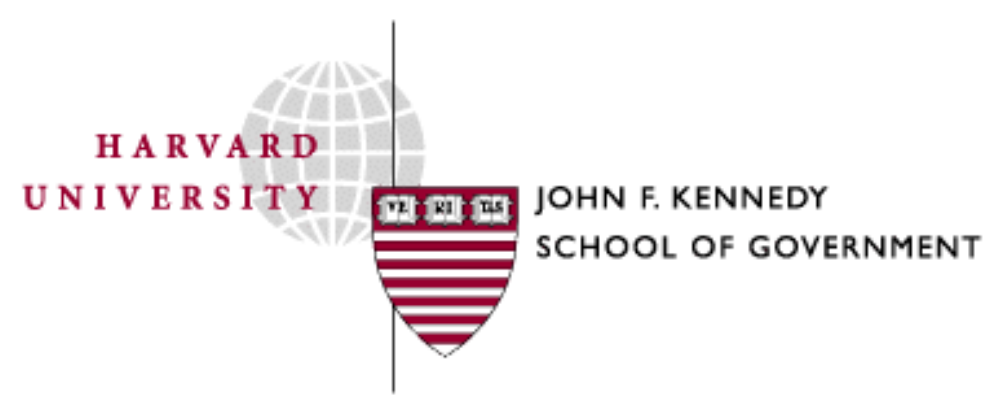

Faculty Research Working Papers Series

\title{
Status and Distrust: \\ The Relevance of Inequality and Betrayal Aversion
}

Kessely Hong and Iris Bohnet

September 2004

RWP04-041

(Revised March 2005)

The views expressed in the KSG Faculty Research Working Paper Series are those of the author(s) and do not necessarily reflect those of the John F. Kennedy School of Government or Harvard University. Copyright belongs to the author(s). Papers may be downloaded for personal use only. 


\title{
Status and Distrust:
}

\section{The Relevance of Risk, Inequality and Betrayal Aversion}

\author{
Kessely Hong and Iris Bohnet ${ }^{*}$
}

\begin{abstract}
Trust is related to people's willingness to accept vulnerability, composed of their willingness to accept the risk of being worse off than if they had never trusted, the risk of being worse off than the trusted party, and the risk of being betrayed by the trusted party. We examine how people's status, focusing on sex, race, age and religion, affects their willingness to accept these three risks. We experimentally measure a person's willingness to accept risk in a Decision Problem, a Risky Dictator Game and a Trust Game. Groups typically considered having lower status in the US-women, minorities, younger people and non-Protestants-are averse to inequality while higher status groups - male, white, older and Protestant decision makers_-dislike being betrayed. This heterogeneity in motivation asks for different organizational interventions to decrease distrust depending on a group’s status.
\end{abstract}

Keywords: Trust; Status; Risk; Inequality; Betrayal; Laboratory experiments.

\footnotetext{
* Kennedy School of Government, Harvard University, 79 JFK Street, Cambridge, MA 02138, phone: (617)495-5605, fax: (617)496-5747, email: Kessely_Hong_2000@ksgalum.harvard.edu., Iris_Bohnet@Harvard.edu

We thank Max Bazerman, Hannah Riley Bowles, Kathleen McGinn and Richard Zeckhauser for their most helpful comments, and Fiona Greig, Ted Hong, and Marc Manara for their excellent research assistance. Financial support from the Program on Negotiation (PON), the Center for Basic Research in the Social Sciences (CBRSS) and the Women and Public Policy Program (WAPPP) at Harvard is gratefully acknowledged.
} 


\section{Why people do not trust others}

Distrust is pervasive in the US and elsewhere. Fifty six percent of Americans do not believe that “most people can be trusted," but think that “you can’t be too careful” in dealing with others. Throughout the world, distrust is even higher, with sixty-nine percent of respondents not believing that "most people can be trusted". 1 A 2002 survey of forty nine communities in the US found similar results when asking the same question (Rahn, Yoon, Lipson, \& Garet, 2002). Experiments designed to elicit behavioral responses also suggest low levels of trust in others in one-shot interactions. For example, in binary-choice trust games where people can either trust or end the relationship, on average about two thirds of the subjects are unwilling to trust, varying with the degree of risk involved when trusting (e.g., Bohnet \& Huck, 2004; Malhotra, 2004; and for a survey, Camerer, 2003).

The lack of generalized trust in others decreases democratic stability (Inglehart, 1999), government performance (Putnam, 1993; La Porta, Lopez-de-Silanes, Shleifer and Vishny 1997; Knack, 2002), and inter-organizational cooperation (Mayer, Davis, \& Schoorman, 1995; Smith, Carroll, \& Ashford, 1995; Kramer \& Tyler, 1996). Distrust contributes to economic stagnation (Fukuyama, 1995; Knack \& Keefer, 1997; Zak \& Knack, 2001) and is associated with lower individual income (Slemrod \& Katuscak, 2002). It goes hand in hand with lower levels of social capital (Putnam 1995, 2000), increased crime (Rosenfeld, Messner, \& Baumer, 2001), inferior student achievement (Putnam 2000), and decreased health and happiness (Helliwell 2002; Kawachi, Kennedy, Lochner, \& Prothrow-Smith, 1997).

\footnotetext{
${ }^{1}$ The data presented are from question 27 in the 1981, 1990-1991 and 1995-1996 World Values Surveys combined. The World Values Surveys are conducted throughout the world in 65 countries by a team of researchers led by Ronald Inglehart of the Institute for Social Research at the University of Michigan.
} 
This paper examines why people do not trust others. We hypothesize that the reasons for distrust are related to a person's status. Status has been defined as holding "high rank on some dimension that is held by society to be important” (Ball \& Eckel, 1996, p.381), and as "the outcome of an evaluation of attributes that produces differences in respect and prominence” (Keltner, Gruenfeld and Anderson, 2003, p.266). We focus on demographic groups generally considered to have high or low social status in the US: men, Caucasians, Protestants, and older people vs. women, members of minority groups, other religions, and younger people, respectively.

We adopt the definition of trust recently proposed by a cross-disciplinary review as “a psychological state composing the intention to accept vulnerability based on positive expectations of the intentions or behavior of another” (Rousseau, Sitkin, Burt, \& Camerer 1998, p. 395). The Trust Game (Dasgupta 1988, Camerer \& Weigelt 1988, Kreps 1990) allows the measurement of trust behavior in the laboratory. In the Trust Game, a decision-maker decides whether or not to trust an anonymous counterpart. If she does not trust, ${ }^{2}$ the game ends and both parties receive a moderate outcome. If she trusts, the trusted party can either reward or betray trust. If he rewards trust, both he and the decision-maker are better off than if trust had not been offered. If he betrays trust, he receives the highest possible and the decision-maker the lowest possible outcome. In either case, trust increases efficiency and the trusted party's earnings. At the same time, trust may make the decision-maker worse off than if she had not trusted and enhance payoff differences between the two parties (in case of betrayal). In this game, decisionmakers make themselves vulnerable by trusting, based on their beliefs about their counterpart's trustworthiness.

\footnotetext{
${ }^{2}$ For simplicity, we refer to decision-makers as female and second players as male.
} 
Much previous research has focused on explanations for why different groups might have different estimates of the likelihood of trustworthiness vs. betrayalessentially, suggesting causes for different levels of optimism. For example, "experiential views" of trust assume that willingness to trust is based on the frequency of successful trust interactions in prior life experiences; people who have been privileged or treated well in the past are more likely to assume they will be treated well in the future and therefore to trust than people who have been treated poorly (see Hardin, 2002; Rotter, 1980; Brehm \& Rahn, 1997; Smith, 1997). Along these lines, Alesina and LaFerrara (2002) argue that groups facing historic discrimination are less trusting.

We focus on the first part of the trust definition and study the factors that might influence a person's willingness to accept vulnerability. Our predictors are independent of people's estimates of the likelihood of trustworthiness. Presumably, everyone would be more inclined to trust when the odds of betrayal are low than when they are high. However, for a given probability of betrayal, some people may choose to trust and others may not. What is it, aside from subjective probability estimates of success, that makes these risky trusting situations appealing to some and unappealing to others?

We decompose the willingness to accept vulnerability into three components: the willingness to accept the risk of being worse off than if one had not trusted; the willingness to accept the risk of being worse off than one's counterpart, the trusted party; and the willingness to accept the risk of being betrayed by the trusted party. ${ }^{3}$

The first component of vulnerability is based on a person's attitude toward risk. We use a behavioral definition of attitudes to risk here. Incidentally, "those who coined the term risk aversion had in mind the psychological interpretation that someone who

\footnotetext{
${ }^{3}$ Note that we assume preferences are stable (additive).
} 
prefers the EV of a gamble over playing the gamble does not like to take risks" (von Winterfeldt \& Edwards, 1986, p. 256). We describe a net effect—a person's willingness to accept the gamble of trust depends on the costs she incurs if the worst possible outcome is realized and the benefits she derives from receiving the best possible outcome. The second vulnerability component builds on recent work on fairness suggesting that people do not like to be worse off than others (e.g., Loewenstein, Thompson, \& Bazerman, 1989; Fehr \& Schmidt, 1999; Bolton \& Ockenfels, 2000). Again, a person's willingness to accept the risk of inequality involved in trust is a net effect, based on a person's concerns for another person's payoffs, such as altruism and/or inequality aversion, and a person’s efficiency preferences (e.g., Andreoni \& Miller 2002, Charness \& Rabin 2002). A person's willingness to accept the risk of betrayal inherent in the trust decision, the third vulnerability component, also gives us a net effect, based not only on concerns about betrayal but also about trustworthiness. While a person may dislike experiencing betrayal, she may also enjoy experiencing trustworthiness. The more averse an individual is to the (net) risk of being worse off, the (net) risk of inequality and the (net) risk of betrayal, the less likely she is to trust.

Most research on trust and vulnerability has focused on the first vulnerability component, a person's attitude toward risk, both theoretically (e.g., Luhmann, 1979; BenNer \& Putterman, 2001; Cook \& Cooper, 2003) as well as experimentally (e.g., Snijders \& Keren, 1988; Schechter, 2003; Malhotra, 2004; Eckel \& Wilson, in press). Recently, Ashraf, Bohnet and Piankov (2003) and Bohnet and Zeckhauser (in press) questioned the widely held assumption that the decision to trust can be conceptualized as just another investment decision under uncertainty. Ashraf et al. show that trust is also closely related 
to people’s concerns about the other's payoff—-the second vulnerability component—and Bohnet and Zeckhauser show that concerns about betrayal come into play when people have to decide whether or not to trust - the third vulnerability component. The possibility of “altruistic trust” has also been noted by Mansbridge (1999) and Kramer (1999), who observes: “Trust needs to be conceptualized not only as a calculative orientation toward risk, but also a social orientation toward other people and toward society as a whole.” (p. 573)

While the relationship between trust and betrayal aversion has not been studied widely, Koehler and Gershoff (2003) suggest that people are deeply concerned about betrayal. Their recent survey on criminal and product safety betrayals finds that subjects feel worse and assign larger (hypothetical) punishments to intentional betrayals than to accidental non-fulfillments with equivalent payoff consequences. Intentional betrayals violate a duty or break a promise (Koehler \& Gershoff, 2003, p. 244). More generally, betrayal aversion is in line with recent theoretical models and empirical evidence that people care about how outcomes came to be. People may care about the process because it allows them to make attributions about their counterpart’s intentions (Rabin 1993; Blount, 1995; Bolton, Brandts, \& Ockenfels, 2000; Charness \& Rabin, 2002), or because they have procedural preferences (e.g. Lind \& Tyler 1988; Oberholzer-Gee, Bohnet, \& Frey, 1997; Frey, Benz, \& Stutzer, 2002). ${ }^{4}$

\footnotetext{
${ }^{4}$ Trustworthiness benefits and betrayal costs are also in line with recent findings in neuroscience. Functional MRI scans reveal in a prisoner's dilemma game that rewarded trust is associated with activation of brain areas linked with reward processing (nucleus accumbens, ventromedial frontal/orbifrontal cortex and rostral anterior cingulated cortex) (Rilling et al. 2002). In contrast, unfairness in an ultimatum game triggers activity in an area of the brain well known for its involvement in negative emotions (the anterior insula) (Sanfey et al. 2003).
} 
Our paper builds on the conceptual framework introduced by Bohnet and Zeckhauser (in press) which allows for the evaluation of the relative importance of the three possible motives for distrust: attitudes toward general risk, the risk of inequality and the risk of betrayal. Here, we are particularly interested in the less-studied risk of inequality and risk of betrayal. We modify the framework to examine how these motives for distrust are related to the status characteristics, sex, ethnicity, religion and age. We focus on general status characteristics applying across situations rather than specific characteristics dependent upon the specific role or power structure of a given situation (Berger, Cohen, \& Zelditch, 1972; Ball \& Eckel, 1996; Ridgeway, Berger, \& Smith, 1985) and limit our inquiry to the effect one’s own status has on people’s willingness to accept vulnerability in different decision situations.

\subsection{Implications of Status on Willingness to Accept Vulnerability}

Status has long been studied by sociologists as a means of predicting social interactions. Expectation States Theory asserts that people use general status characteristics as a basis for guiding their own and predicting others' behaviors, most notably in the absence of other personal information (Meeker \& Weitzell-O’Neill, 1977, Ridgeway, Berger \& Smith, 1985).

Since status is socially conferred, its impact on behavior depends on the society in which one is living. We limit our status evaluations to the US because that is where we conduct our study. Most of the research on status has focused on sex. In fact, sex has been found to be such a strong indicator of status that some have termed it the "master status” (Hughes, 1945). Men are generally acknowledged to hold higher status than 
women (Lips 1991). Similarly, in the US, Caucasians, Protestants and older, more experienced people are considered to have higher status than their respective counterparts. Everyone has multiple facets for which status could be considered; holding high status along several dimensions should yield the highest overall status, and similarly holding low status along several dimensions should yield the lowest overall status. In analogy to a popular acronym describing a particularly powerful group in the US, "WASPs," white Anglo-Saxon Protestants, the group comprising the highest status in our study are "WOMPs," white, older, male Protestants.

The impact of status on behavior is pervasive. General status characteristics have been found to influence behavior not only in everyday life, but also in experimental laboratory settings where all participants are nominally assigned to the same role and given the same level of resources (Berger, Cohen \& Zelditch 1972; Berger, Fisek, Norman \& Zelditch 1977). Eagly observes that experimental participants see sex, for example, as a "status cue because of their extensive prior experience in natural settings where sex was observed to be correlated with power and prestige” (Eagly, 1983, p.975).

\subsubsection{Status and willingness to accept the risk of inequality}

By trusting, people expose themselves to the risk of ending up worse off than the trusted party. At the same time, by trusting, they increase efficiency and make the trusted party better off than he would have been if no trust had been offered. Status theory suggests that low status groups are more concerned about equality and less about making someone else better off than high status groups. Meeker \& Weitzel-O’Neill (1977) argue that low status persons’ preferences for equality developed because other allocation 
procedures, such as, for example, equity, do not serve them well. They feel that absent equality, they generally do not get what they deserve to receive as their input is not considered as valuable as a high status person's input, keeping everything else equal.

The high status group's willingness to make someone else better off can be seen in two lights: first, as altruism and second, as a "warm glow" to the benefactor, confirming his or her own superiority and largesse. Both non-selfish and selfish motives such as a "warm glow" have been found to affect regard for others in a wide variety of circumstances (see, e.g., Andreoni, 1990 and for a survey, Fehr \& Schmidt, 2002). In this way, generosity also serves as a means for high status benefactors to preserve their own status (Jackman, 1994; Swim \& Campbell, 2003). In the particular case of male donors and female recipients, research suggests "chivalry" and "paternalism”: men see women as objects to protect and treasure (Glick \& Fiske, 1996), but also as inferior (Nadler \& Morrow, 1959). We predict:

H1: Members of low status groups are less willing to accept the risk of disadvantageous inequality than members of high status groups.

\subsubsection{Status and the Willingness to Accept the Risk of Betrayal}

By trusting, people expose themselves to the risk of being betrayed by the trusted party. They cede power over their own outcome to the trusted party and accept some degree of submission to another's will. Members of high status groups are more used to assuming powerful roles than members of low status groups (Lips, 1991). Stereotypes can lead groups to be identified (by themselves and others) with the characteristics thought to pertain to the roles held by the group (Jost \& Banaji, 1994; Hoffman \& Hurst, 
1990). Multiple research studies suggest than men are more likely than women to view themselves as powerful and strong (e.g., Maccoby \& Jacklin, 1974; and for a literature review; Ashmore, 1981). In fact, most boys (but not girls) are raised from birth to “develop a premise system that presumes or anticipates mastery, efficacy, and instrumental competence” (Block, 1984, p.131). In general, belonging to a high status category is a predictor of dominant behavior (Meeker \& Weitzel-O’Neill 1977, Lips, 1991).

In contrast, "young women are socialized to turn their fates over to others and to wait to see what happens rather than to exert too much active control over their own lives” (Lips, 1991, p.77). Low status groups have been found to be more willing to accept powerlessness (Mainiero, 1986) and to be more likely to opt for a democratic, or communal, leadership style as opposed to an authoritative, commanding style (Eagly \& Johnson, 1990; Geis, Brown, Jennings, \& Corrado-Taylor, 1984). Unlike members of high status groups, whose assertive behavior is widely accepted, members of low status groups are expected to be compliant to the will of others. In keeping with Expectation States Theory, it is difficult for members of low status groups to lead authoritatively in mixed-status settings, even when they possess nominal leadership titles (Ridgeway \& Berger, 1986).

Unbalanced power relations, such as between the trusting and the trusted parties, are unstable and are likely to lead to a variety of "cost reduction" actions or "balancing operations” (Emerson, 1962, p.33). High status decision-makers confronted with the decision of whether or not to trust are likely to choose a balancing action that increases their control: namely, quitting the relationship. As Emerson describes, "the denial of 
dependency involved in this balancing operation will have the effect of moving actors away from relations which are unbalanced to their disadvantage” (Emerson, 1962, p.36).

Women, minorities, non-Protestants and young people—members of lower status groups - are less accustomed to holding power, viewing themselves as powerful, and acting to protect their power. They tend to focus on "cost reduction" strategies: rather than fighting against their lack of power, they change their own outlook and values in order to decrease the pain of giving in to the other, more powerful, person. (Emerson, 1962, p.35). We predict:

H2: Members of low status groups are more willing to accept the risk of betrayal than members of high status groups.

\section{Conceptual Framework}

Building on the methodology introduced by Bohnet and Zeckhauser (in press), we compare responses to three games: the "Decision Problem," the "Risky Dictator Game” and the "Trust Game," in order to assess different causes for distrust. The Decision Problem (DP) measures people’s willingness to accept general risk. In the DP, people are confronted with a certain payoff and a gamble yielding one outcome higher and one lower than the certain payoff. In our study, the certain payoff is worth $\$ 10$, whereas the gamble yields either $\$ 15$ or $\$ 8$.

Usually, when risk assessment questions similar to this one are used in experimental settings, participants are told the probability of getting the higher outcome in the gamble and are asked whether they want the gamble or the certain payoff (e.g., Siegrist, Cvetkovich, \& Gutscher, 2002). In our study, participants are told only that if 
they choose the gamble, their payoff will be determined by a random draw. Participants are asked (in simpler language) to name their Minimum Acceptable Probability (MAP) of gaining the higher payoff in the gamble which makes them prefer the gamble to the sure payoff of $\$ 10$. If the MAP is equal to or less than the actual likelihood of getting the higher payoff, then the decision-maker receives the gamble and his or her result is determined by the random draw; if the MAP is higher than the actual likelihood of getting the higher payoff, then the decision-maker receives $\$ 10$. Participants are informed that the actual likelihood of getting the higher payoff has been determined before the beginning of the study. It is $\mathrm{p}^{*}=0.29$ and corresponds to the likelihood of trustworthiness found in the Trust Game. ${ }^{5}$ Coincidentally, it is also the probability that makes a risk neutral decision-maker indifferent between choosing the sure outcome and the gamble.

From the DP, we can learn a participant's general attitude to risk. Since the probability of getting the higher payoff of $\$ 15$ instead of $\$ 8$ that would make the expected value of the gamble equal to the sure $\$ 10$ outcome is 0.29 , by subtracting 0.29 from the participant's $\mathrm{MAP}_{\mathrm{DP}}$, we get his or her risk attitude: a positive score indicates risk-aversion, zero (an MAP of exactly 0.29) indicates risk-neutrality, and a negative score indicates risk-seeking behavior.

The Risky Dictator Game (RDG) ${ }^{6}$ is similar to the Decision Problem, but adds another level of complexity. Here, again, participants confront a choice between a certain

\footnotetext{
${ }^{5}$ See Bohnet and Zeckhauser (in press). They also explain why this mechanism is incentive compatible, i.e., induces people to reveal the truth.

${ }^{6}$ The word "Dictator" in the title of this game is a nod to the classic "Dictator" game (Kahneman, Knetsch and Thaler 1986), in which participants are given an amount of money and told they can share all, some, or none of it with someone else. The word "Risky" refers to the fact that the decision-maker faces some risk regarding the outcome of his or her decision.
} 
outcome and a gamble whose outcome is determined by a random draw. Also, as before, they are asked to name the MAP of getting the higher payoff instead of the lower payoff that makes them prefer the gamble to the certain payoff. However, their decision now affects not only themselves but also another, randomly selected, unidentified, participant. The certain outcome yields payoffs of $\$ 10$ each to both the decision-maker and the other participant with whom she is paired. The gamble results either in payoffs of $\$ 15$ each to both the decision-maker and the other participant or $\$ 8$ to the decision-maker and $\$ 22$ to the other participant.

As with the Decision Problem, one factor which is likely to affect the decisionmaking process in the RDG is the decision-maker's own risk attitude. Additionally, the decision-maker may also care about the payoffs received by the other person as a result of her choice. In order to figure out how prominently concerns about the other's payoffs factor into the decision, aside from the decision-maker's own risk attitude, we can subtract the $\mathrm{MAP}_{\mathrm{DP}}$ from the $\mathrm{MAP}_{\mathrm{RDG}}$. This yields a measure of a person's willingness to accept the risk of inequality. A positive difference between the $\mathrm{MAP}_{\mathrm{RDG}}$ and the $\mathrm{MAP}_{\mathrm{DP}}$ indicates that the decision-maker is averse to the risk of inequality; if the $\mathrm{MAP}_{\mathrm{RDG}}$ minus the $\mathrm{MAP}_{\mathrm{DP}}$ is negative, this suggests that the decision-maker seeks the risk of inequality—because she likes making someone else better off or has efficiency preferences and these motives outweigh any concerns about payoff differences.

The final game in this framework is a modified version of the Trust Game (TG) introduced earlier. From the standpoint of the decision-maker, it is identical to the RDG, except that if the gamble is chosen then the outcome is decided by the other person, the 
trusted party, rather than by nature. ${ }^{7}$ As before, the payoffs are $\$ 10$ each to both parties if the sure option is chosen, and either $\$ 15$ each to both parties or \$8 to the decision-maker and $\$ 22$ to the trusted party if the gamble is chosen.

The way this works is as follows: the second parties are told the structure of the game and that they will be randomly paired with an unknown decision-maker. Then, they are asked which of the two outcomes (\$15 decision-maker and \$15 to self vs. \$8 to decision-maker and $\$ 22$ to self) they choose in case the decision-maker selects the gamble. The fraction of trusted parties choosing $\$ 15 / \$ 15$ from the gamble outcome is then calculated. The decision-makers, who know they will be randomly paired with an unknown counterpart, are simultaneously asked for their MAP of being paired with a counterpart who chose the $\$ 15 / \$ 15$ outcome to make them prefer the gamble to the certain option.

If the MAP named by a particular decision-maker is equal to or less than 0.29 , the fraction of trusted parties having chosen the $\$ 15 / \$ 15$ outcome, then the decision-maker and her randomly selected counterpart are in the gamble scenario and the outcome is decided by that particular trusted party’s choice; if the decision-maker's MAP is higher than the fraction of trusted parties having chosen the $\$ 15 / \$ 15$ outcome, then both people in the pair receive $\$ 10$ each.

This game incorporates all the potential decision-making concerns as the previous game (attitude to risk and inequality) as well as a new possible concern: betrayal. By subtracting the $\mathrm{MAP}_{\mathrm{RDG}}$ from the $\mathrm{MAP}_{\mathrm{TG}}$, we can calculate a measure for a decisionmaker’s willingness to accept the risk of betrayal. Positive values indicate betrayal risk

\footnotetext{
${ }^{7}$ For related designs also comparing decisions made by a person with outcomes determined by nature in the Ultimatum Game, see Blount (1995), Pillutla and Murnighan (1996); Bolton, Brandts and Ockenfels (2000).
} 
aversion, while negative values indicate that the decision-maker seeks the risk of betrayal—because he or she enjoys experiencing rewarded trust and such concerns outweigh any dislike of experiencing betrayal.

To study the impact of status, we collect demographic information on sex, ethnicity/race (African or African-American, Arab, Asian or Pacific Islander, Caucasian, Hispanic, Native American, or Other), religion (Buddhist, Catholic, Hindu, Jewish, Muslim, Orthodox Christian, Protestant, None, or Other) and age in a post-experimental questionnaire. To give what has been termed the "master status," special salience, we examine sex in more detail. We study same-sex and mixed-sex pairs in the Risky Dictator and the Trust Game. The sex of their counterpart is known to all subjects in all conditions.

\section{Experiment}

\subsection{Method}

\subsubsection{Participants}

Two hundred and ninety nine subjects participated in the experiment. Participants were recruited from colleges in the greater Boston area. While the majority of participants in this subject pool typically are students, there is always a sizable number of community members older than the typical student participating. There is a pretty even gender split, with 49 percent females and 51 percent males. In terms of ethnicity, 62 percent are Caucasian, 19 percent Asian or Pacific Islander, 10 percent African or African-American, 7 percent Hispanic, 1 percent Arab, and there is one Native American participant. Most of the subjects are 30 or younger-in fact, more than we had hoped (90 
percent). Almost one third of participants (31 percent) are not religious; of those participants who espouse a religion, Protestants comprise the largest category at 22 percent, followed by Catholics at 20 percent, Jews at 11 percent, Buddhists at 4 percent, Hindus at 3 percent, Orthodox Christians at 2 percent, and Muslims at 2 percent (5 percent listed “other”).

Participants received a $\$ 10$ show-up fee, plus additional earnings ranging from $\$ 8$ to $\$ 22$. We ran 8 experimental sessions, each taking approximately one hour. All sessions were run at Harvard University in February and March, 2004.

\subsubsection{Design and procedure}

We employ a complete 3x2 between-subject design, with three decision situations and male or female decision-makers. In addition, in the decision situations involving a second person, the Risky Dictator and the Trust Game, we also vary the second person's sex. Each participant took part in only one treatment condition.

Upon entering a session, each participant was asked to sign a consent form and received an index card with a code number to be used for identification purposes during the experiment. Then, an introduction was distributed, followed by the instructions for the specific decision situation for that session (DP, RDG, or TG), and then a questionnaire. During the questionnaire period, the researchers examined whether each

person or pair ended up with the certain option or the gamble, and began to calculate payments. After the questionnaires were completed, the researchers explained how the payments would work, identified the code numbers of the individuals or pairs participating in the gamble, and conducted the lottery (DP and RDG) or revealed the 
second party's decisions (TG). Payment was made to subjects in sealed envelopes, identified by code numbers. Appendix A contains sample instructions for the decisionmaker in the Trust Game.

\subsection{Results}

Decision makers' status is related to their willingness to accept both the risk of inequality and the risk of betrayal. To measure attitudes toward these risks, we focus on decision makers’ MAPs. We report means and medians but will base our analysis on means.

The difference between a group's mean MAP in the Decision Problem and the value of $\mathrm{p}$ that would leave a risk neutral person indifferent between choosing the sure outcome and the lottery, $\mathrm{p}=0.29$, indicates a group's attitude toward general risk. All our demographic groups are risk averse- their MAPs in the Decision Problem exceed $\mathrm{p}=0.29$. The difference between a group's mean MAPs in the Risky Dictator Game and the Decision Problem indicates a group's attitude toward the risk of inequality, and between a group's mean MAPs in the Trust Game and the Risky Dictator Game a group’s attitude toward the risk of betrayal. To compare the behavior of different status groups, we conduct non-parametric tests for differences in means (Mann-Whitney U test). ${ }^{8}$ All pvalues reported are based on this test. We do not find significant differences according to the second player's sex and thus combine our data across male and female second players. The results are summarized in Table 1.

\footnotetext{
${ }^{8}$ The Mann-Whitney or Wilcoxon test is an alternative to the parametric t-test, whose assumptions do not apply to our data (or to most experimental data, for that matter), see, e.g., Siegel and Castellan (1988).
} 
Table 1: MAPs in the three decision situations (mean, median, [N])

\begin{tabular}{|l|l|l|l|}
\hline & Decision Problem & $\begin{array}{l}\text { Risky Dictator } \\
\text { Game }\end{array}$ & Trust Game \\
\hline All & $\mathbf{0 . 4 0}$ & $\mathbf{0 . 3 9}$ & $\mathbf{0 . 4 6}$ \\
& 0.35 & 0.40 & 0.44 \\
& {$[37]$} & {$[57]$} & {$[74]$} \\
\hline Men & $\mathbf{0 . 4 1}$ & $\mathbf{0 . 3 4}$ & $\mathbf{0 . 4 1}$ \\
& 0.35 & 0.32 & 0.44 \\
& {$[16]$} & {$[32]$} & {$[31]$} \\
\hline Women & $\mathbf{0 . 3 9}$ & $\mathbf{0 . 4 7}$ & $\mathbf{0 . 4 9}$ \\
& 0.40 & 0.50 & 0.50 \\
& {$[21]$} & {$[25]$} & {$[43]$} \\
\hline Caucasians & $\mathbf{0 . 4 4}$ & $\mathbf{0 . 3 5}$ & $\mathbf{0 . 4 6}$ \\
& 0.43 & 0.34 & 0.44 \\
& {$[18]$} & {$[35]$} & {$[46]$} \\
\hline Minority (all non- & $\mathbf{0 . 3 5}$ & $\mathbf{0 . 4 6}$ & $\mathbf{0 . 4 6}$ \\
Caucasian) & 0.30 & 0.48 & 0.46 \\
& {$[18]$} & {$[22]$} & {$[28]$} \\
\hline Old (ages 31-59) & $\mathbf{0 . 4 5}$ & $\mathbf{0 . 2 0}$ & $\mathbf{0 . 4 4}$ \\
& 0.45 & 0.10 & 0.46 \\
& {$[6]$} & {$[5]$} & {$[10]$} \\
\hline Young (ages 18-30) & $\mathbf{0 . 3 9}$ & $\mathbf{0 . 4 1}$ & $\mathbf{0 . 4 6}$ \\
& 0.35 & 0.40 & 0.44 \\
& {$[30]$} & {$[52]$} & {$[64]$} \\
\hline Protestant & $\mathbf{0 . 4 4}$ & $\mathbf{0 . 3 1}$ & $\mathbf{0 . 4 5}$ \\
& 0.45 & 0.33 & 0.45 \\
& {$[6]$} & {$[15]$} & {$[20]$} \\
\hline Non-Protestant & $\mathbf{0 . 3 9}$ & $\mathbf{0 . 4 2}$ & $\mathbf{0 . 4 6}$ \\
& 0.35 & 0.40 & 0.45 \\
& {$[31]$} & {$[42]$} & {$[54]$} \\
\hline
\end{tabular}

\subsubsection{Attitude toward the Risk of Inequality}

Status is strongly related to people's willingness to accept the risk of inequality.

Low status groups exhibit strong inequality risk aversion while high status groups show strong inequality risk proneness $(\mathrm{p}<0.01$ for men versus women and Caucasians versus minorities, $\mathrm{p}=0.034$ for older versus younger, and $\mathrm{p}=0.037$ for Protestants vs. nonProtestants). This suggests that concerns about disadvantageous payoff differences outweigh regard for others or considerations about efficiency in low status groups while 
the reverse is true for high status groups, supporting Hypothesis 1. The mean attitude to the risk of inequality by status group can be seen in Figure 1 .

Figure 1: Attitude to Inequality Risk by Status Group (mean $\mathrm{MAP}_{\mathrm{RDG}}$-mean $\mathrm{MAP}_{\mathrm{DP}}$ )

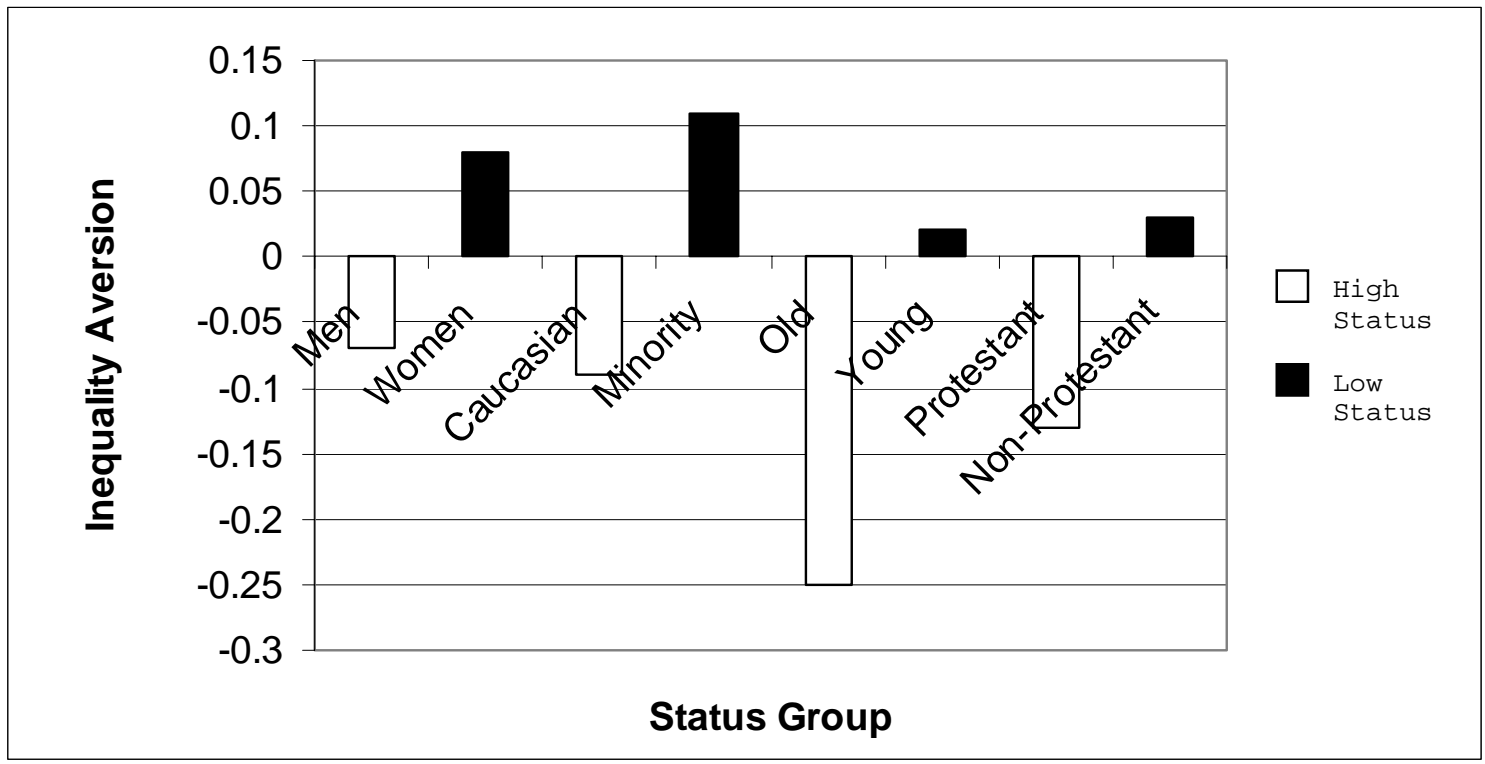

The status differences in the willingness to accept the risk of inequality are magnified when comparing groups holding high vs. low status on multiple dimensions. For example, Caucasian men's MAPs drop from 0.45 in the Decision Problem (N=8) to 0.31 in the Risky Dictator Game $(\mathrm{N}=20)$ while Minority women’s MAPs increase from 0.33 in the Decision Problem ( $\mathrm{N}=10)$ to 0.57 in the Risky Dictator Game $(\mathrm{N}=10)$. Similarly, Protestant men's MAPs decrease from 0.50 in the DP $(\mathrm{N}=3$ !) to 0.26 in the RDG (N=11) while non-Protestant women's MAPs jump from 0.39 in the $\mathrm{DP}(\mathrm{N}=18)$ to 0.47 in the RDG $(\mathrm{N}=21)$. Despite the small sample sizes, these differences are both highly significant $(\mathrm{p}<0.01)$. Appendix B presents the results for various status combinations. While the sample sizes typically get very small, double-category status generally enhances single-category status differences. 


\subsubsection{Attitude toward the Risk of Betrayal}

Greater status is associated with significantly greater betrayal risk aversion for most of our status categories, mostly supporting Hypothesis 2 . The status-related difference in betrayal risk aversion is highly significant for older vs. younger people, with $\mathrm{p}<0.01$; moderately significant for Caucasians vs. minorities, with $\mathrm{p}=0.090$, and for Protestants vs. non-Protestants, with $\mathrm{p}=0.098$; but not significant for men vs. women, with $\mathrm{p}=0.280$. Betrayal costs generally outweigh trustworthiness benefits in high status groups while the two motives nearly cancel each other out in low status groups, leading to no or only small differences between the Trust and the Risky Dictator Game MAPs. The mean attitude to betrayal risk by status group can be seen in Figure 2 .

Figure 2: Attitude to Betrayal Risk by Status Group (mean $\mathrm{MAP}_{\mathrm{TG}}$-mean $\mathrm{MAP}_{\mathrm{RDG}}$ )

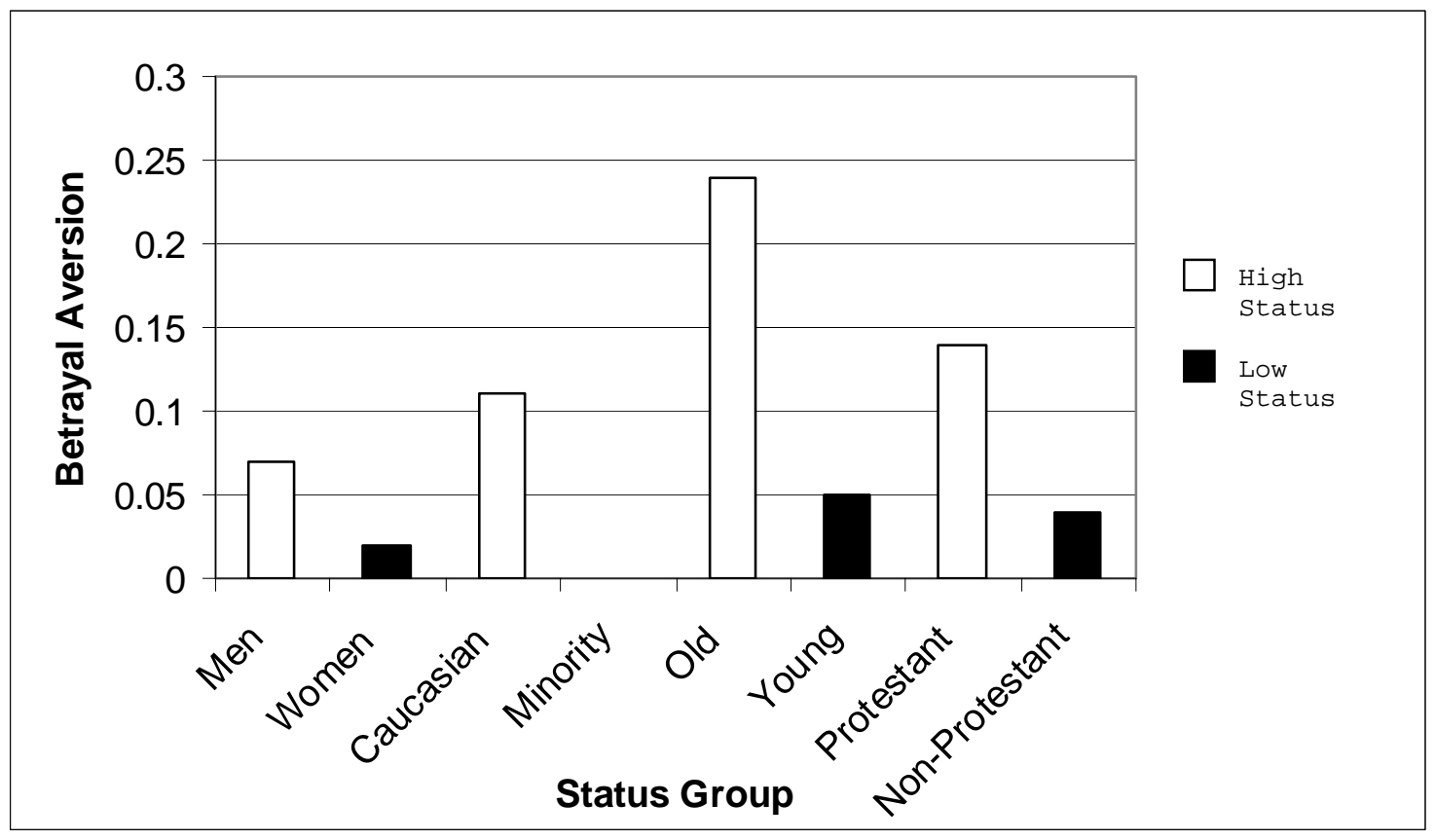

(Note: the value for Betrayal Aversion for the minority status group does not appear on the graph because it is 0.0.) 
The status differences in willingness to accept the risk of betrayal are again larger when comparing groups holding high vs. low status on multiple dimensions. For example, Caucasian men's MAPs increase from 0.31 in the Risky Dictator Game (N=20) to 0.44 in the Trust Game (N=20) while Minority women’s MAPs slightly drop from 0.57 in the Risky Dictator Game to 0.54 in the Trust Game $(\mathrm{N}=17)(\mathrm{p}=0.01)$. Likewise, Protestant men's MAPs go up from 0.26 in the RDG $(\mathrm{N}=11)$ to 0.45 in the TG $(\mathrm{N}=12)$ while non-Protestant women's MAPs remain similar across the two games, at 0.47 in the RDG $(\mathrm{N}=21)$ vs. 0.50 in the $\mathrm{TG}(\mathrm{N}=35)(\mathrm{p}=0.03)$. Appendix $\mathrm{B}$ shows that this pattern generally applies to double-status category versus single-status category comparisons.

\subsubsection{Motives for Distrust}

Low status and high status groups are similarly unlikely to trust others. The MAPs of the different status groups in the Trust Game do not significantly differ from each other. However, given the similar degrees of general risk aversion, the motives for distrust are quite different: high status groups do not trust because they fear the risk of betrayal — their betrayal risk aversion compensates for the positive regard they have for others and/or their preferences for efficiency; low status groups do not trust because they are concerned about the risk of inequality, but they are generally indifferent about the risk of betrayal. Figure 3 illustrates this dynamic, showing mean MAPs for each status group in all three decision situations. 
Figure 3: Mean MAPs in the three decision situations by status group

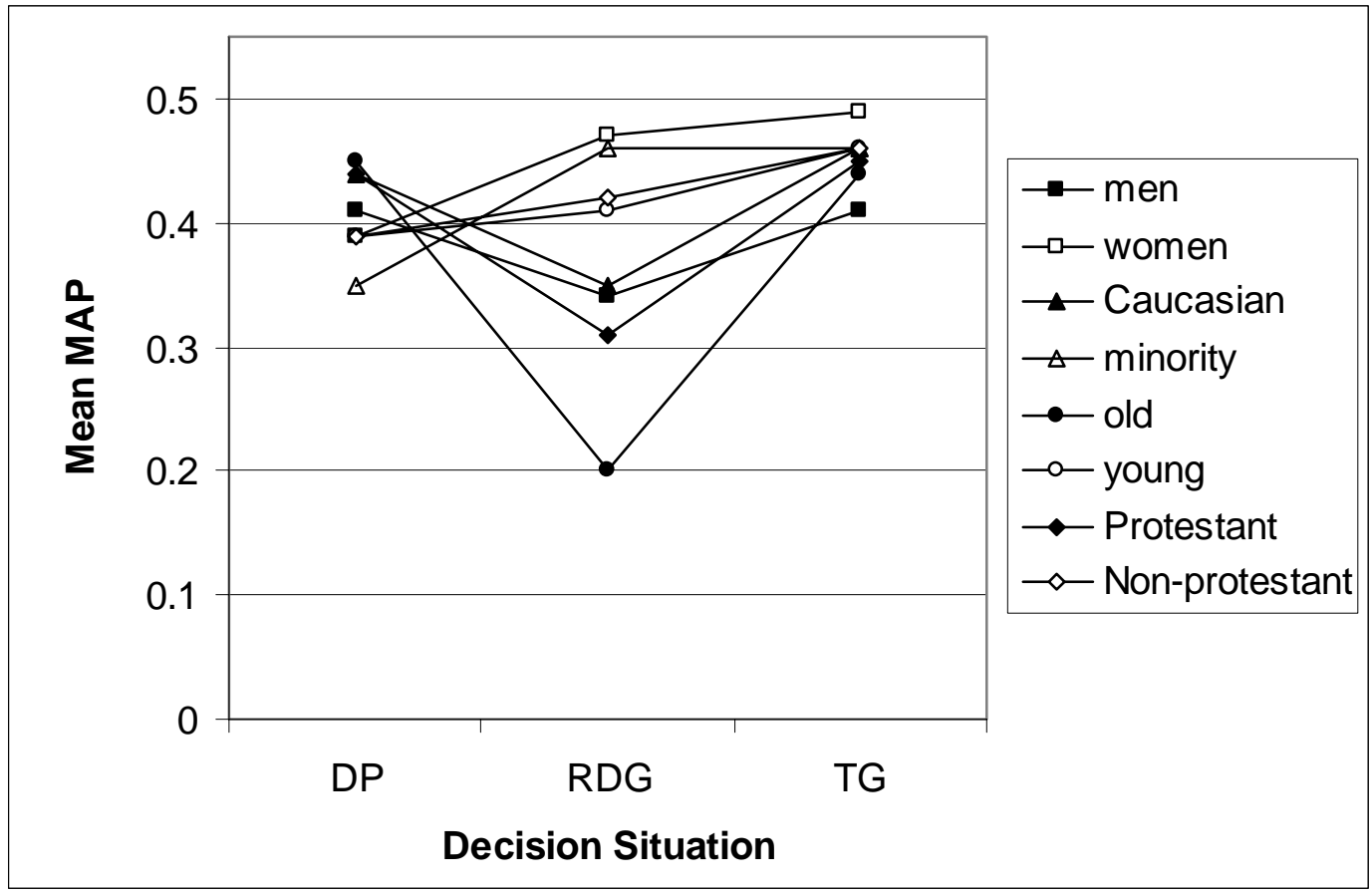

\section{Discussion}

Different status groups' willingness to accept vulnerability is similar in the Decision Problem and in the Trust Game but strongly differs in the Risky Dictator Game. The risk of inequality decreases low status groups' willingness to accept vulnerability but has the opposite effect on high status groups. For the latter, the possibility of efficiency gains and/or of making someone else better off outweigh their concerns about inequality.

To put our findings in the Risky Dictator Game into perspective, we compare our results to related games, such as Dictator and Ultimatum Games, and related decision scenarios involving concerns about equality. While there exists a relatively rich literature on sex differences in these games, research on other status dimensions is rare. In the Dictator Game (Kahneman, Knetsch, \& Thaler, 1986), a dictator receives a certain amount of money, which she can allocate between herself and a second player as she 
wishes. The game ends after her decision. The Ultimatum Game (Güth, Schmittberger \& Schwarze, 1982) differs from the Dictator Game in that the second player determines the final outcome. He can accept or reject the amount allocated to him. If he accepts, the deal stays as proposed by the decision-maker; if he rejects, both earn zero.

In contrast to our Risky Dictator Game, there is no risk involved in the standard Dictator Game, and only occasionally efficiency increases, when decision-makers pass along money. The Dictator Game measures advantageous inequality aversion. For example, in the original game by Kahneman, Knetsch and Thaler (1986), the decisionmaker chooses between keeping $\$ 18$ for herself and giving $\$ 2$ to a second person and splitting the pie equally, allocating $\$ 10$ to each. Focusing on the second person's behavior, the Ultimatum Game is an (albeit imperfect) measure of disadvantageous inequality aversion. ${ }^{9}$

In Dictator Games involving efficiency gains when money is sent to the second person, Andreoni and Vesterlund (2001) and Ashraf et al. (2003) find that men respond more strongly to efficiency gains than women while women are more focused on equality. Women also favor an equal distribution when allocating rewards (Sampson, 1975) and are more inequality averse when choosing among hypothetical societies on behalf of imaginary grandchildren (Carlsson, Daruvala, \&Johansson-Stenman, 2001). Note that in standard Dictator Games where amounts sent are compatible with concerns for equality and regard for others, and efficiency concerns do not come into play, women typically send larger amounts than men (e.g. Eckel \& Grossman, 1998). Finally, African-

\footnotetext{
${ }^{9}$ It is an imperfect measure because it is unclear whether rejections in the Ultimatum Game are due to inequality aversion, based on payoff comparisons, or to reciprocity, based on beliefs about the decisionmaker's intentions. The evidence is mixed and cause for an on-going debate (for a summary of the debate, see Fehr and Schmidt, 2002.
} 
Americans are found to be more likely to reject offers below an equal split in the Ultimatum Game (Eckel \& Grossman, 2001).

We do not find any significant differences in behavior for low and high status groups in the Decision Problem. Schubert et al. (1999) find that men and women are equally risk averse when there is no ambiguity or when facing a specific choice task. Siegrist et al. (2003) also report no significant sex differences in attitudes to risk. Other researchers have found women to be more risk averse than men (Hershey \& Schoemaker, 1980; Powell \& Ansic, 1997; Jianakoplos \& Bernasek, 1998; Carlsson et al, 2001).

We do not know of any research examining the determinants of people's attitudes to betrayal. Previous research on trust has focused on explaining the heterogeneity in trust behavior, while we are more interested in the heterogeneity in the motives accounting for observed behavior. The research focusing on who distrusts rather than on why different groups of people distrust, finds mixed evidence for sex, but that generally, minorities and young people are more likely to distrust others than Caucasians and older people.

As in this study, most trust experiments do not suggest sex differences in trust behavior (e.g., Croson and Buchan 1999; Ashraf, Bohnet and Piankov 2003; Fehr, Fischbacher, von Rosenbladt, Schupp and Wagner 2002). Buchan, Croson and Solnick (2003) find men to be more trusting than women while Eckel and Wilson (2003) find women to be more trusting than men when shown a photo of their counterpart but less trusting when given only information about their counterpart's sex and preferences. Survey evidence generally suggests no sex differences. According to the World Values 
Survey, US men and women have fairly similar rates of trust: approximately $42 \%$ of men and 46\% of women think "most people can be trusted" (WVS, 1981-1995, question 27).

In trust experiments, Glaeser, Laibson, Scheinkmann, \& Soutter (2000), Ashraf et al (2003) and Eckel and Wilson (2003) find that members of minority groups are less trusting than Caucasians. In the World Values Surveys, people who identify themselves as white Americans are more likely to trust (43\%) than people who identify themselves as black, Hispanic, or Asian minorities (25\%). (WVS, 1981-1995, question 27). According to Rahn et al., 2002, Caucasians are about 21\% more likely to trust than AfricanAmericans in the US (holding other factors constant).

In an experimental Trust Game, Sutter and Kocher (2003) find that trust increases throughout childhood into early adulthood, but then flattens out in adulthood. Only 37\% of US respondents to the World Values Surveys between the ages of 18-30 trust, whereas 48\% of respondents ages 31-59 trust (WVS, 1981-1995, question 27). Other surveys also find that younger people are more likely to distrust others than older respondents (Rahn et al, 2002). Based on the GSS (1972-1994), Glaeser et al (2000) find that Protestant denominations (except Baptists) are more trusting than Catholics, Jews, or non-religious people (p.15-16). La Porta et al (1997) finds similar results across the world, based on the World Values Surveys.

\section{Summary and Conclusions}

Trust has been defined as the "willingness to accept vulnerability." We open the black box of vulnerability and argue that people may distrust because they are averse to the risk of being worse off compared to the status quo of no trust, the risk of being worse 
off than someone else and/or the risk of being betrayed by the trusted party. This paper disentangles these effects and shows which motives matter for different groups of people. We focus on demographic groups generally considered to have a high or a low social status: men, Caucasians, Protestants, and older people vs. women, members of minority groups, other religions, and younger people, respectively. A group’s status helps us understand why people do not trust each other.

We employ a method allowing participants to indicate how vulnerable they are willing to be in different situations. Their MAP, the minimal acceptable probability of success, gives us their willingness to choose a gamble over a certain option—-thereby eliminating consideration of different estimates of the probability of betrayal.

We find that all groups are averse to the risk of losing money compared to the status quo. Any policy intervention or management strategy aimed at encouraging trust has to take this into account. Interventions can focus on decreasing the magnitude of the (net) losses involved or the (net) likelihood that the losses will occur. Based on our results, we expect the former strategy to work well for lower status individuals while the latter strategy seems advisable for higher status individuals. Given their risk preferences, people with higher status tend to distrust because they fear betrayal. People with lower status tend to distrust because they have a strong aversion to receiving an inferior outcome compared to their counterpart; the specter of betrayal does not loom large in their consideration.

Institutional mechanisms such as insurance and compensation encourage trust by decreasing general risk and the risk of inequality in case of betrayal. Our results suggest that such protection may successfully enhance lower status groups’ trust. They fear 
losses and comparative disadvantage more than they feel any sting of pride brought on by betrayal. In contrast, higher status individuals will not be as impressed by decreases in losses and payoff differences. To encourage their trust, the potential for betrayal has to be decreased, for example, by creating incentives for the trusted party to be trustworthy. Stricter law enforcement and punishment for breaches of trust, repeated interactions and reputational concerns may align the trusted party's interests. Another route toward improving the willingness to trust of people from high status groups may be to increase the efficiency afforded by trust situations.

Recently, Alan Greenspan remarked: “American capitalism is turning back to trust and integrity as an antidote to corporate scandal.” (Balls, 2004, p.1). This paper suggests that anyone wishing to increase people's willingness to trust may benefit from taking the status differences in the relative importance of various motives into account and use the corresponding institutional devices to address them. 


\section{References}

Alesina, A. \& La Ferrara, E. (2002). Who trusts others? Journal of Public Economics, 85, 207234.

Andreoni, J. (1990). Impure altruism and donations to public goods: A theory of warm-glow giving? Economic Journal, 100, 464-77.

Andreoni, J. \& Vesterlund, L. (2001). Which is the fair sex? Gender differences in altruism. Quarterly Journal of Economics, 116, 293-312.

Andreoni, J. \& Miller, J. (2002). Giving according to GARP: An experimental test of the consistency of preferences for altruism. Econometrica, 70(2), 737-753.

Ashmore, R. D. (1981). Sex stereotypes and implicit personality theory. In D. L. Hamilton (Ed.), Cognitive processes in stereotyping and intergroup behavior (pp. 37-81). Hillsdale, NJ: Erlbaum.

Ashraf, N., Bohnet, I., \& Piankov, N. (2003). Is trust a bad investment? Working paper. Kennedy School of Government, Harvard University.

Ball, S. B. \& Eckel, C. C. (1996). Buying status: Experimental evidence on status in negotiation. Psychology \& Marketing, 13(4), 381-405.

Ben-Ner, A. \& Putterman, L. (2001). Trusting and trustworthiness. Boston University Law Review, 81, 523-551.

Berger, J., Cohen, B. P., \& Zelditch, M., Jr. (1972). Status characteristics and social interaction. American Sociological Review, 37, 241-255.

Berger, J., Fisek, M. H., Norman R. Z., \& Zelditch M., Jr. (1977). Status characteristics and social interaction: An expectation states approach. New York: American Elsevier.

Block, J. H. (1984). Sex role identity and ego development. San Francisco: Jossey-Bass.

Blount, S. (1995). When social outcomes aren't fair: The effect of causal attributions on preferences. Organizational Behavior and Human Decision Processes, 63(2), 131-144.

Bohnet, I. \& Huck, S. (2004). Repetition and Reputation: Implications for Trust and Trustworthiness When Institutions Change. American Economic Review, 94(2), 362-366.

Bohnet, I. \& Zeckhauser, R. J. (in press). Trust, risk and betrayal. Journal of Economic Behavior \& Organization.

Bolton, G. \& Ockenfels, A. (2000). ERC: A theory of equity, reciprocity, and competition. American Economic Review, 90(1), 166-193.

Bolton, G. E., Brandts, J., \& Ockenfels, A. (2000). Fair procedures: Evidence from games involving lotteries. Working paper. Penn State University.

Brehm, J. and Rahn, W.M. (1997). Individual-level evidence for the causes and consequences of social capital. American Journal of Political Science, 41, 999-1023.

Buchan, N., Croson, R., \& Solnick, S. (2003). Trust and gender: An examination of behavior, biases, and beliefs in the investment game. Working paper. The Wharton School, University of Pennsylvania.

Camerer, C. F. (2003). Behavioral Game Theory. Princeton, NJ: Princeton University Press and Russell Sage Foundation.

Camerer, C. \& Weigelt, K. (1998). Experimental Tests of a Sequential Equilibrium Reputation Model. Econometrica, 56(1), 1-36.

Carlsson, F., Daruvala, D., \& Johansson-Stenman, O. (2001). Are people inequality averse or just risk averse? Working Paper in Economics no. 43. Department of Economics, Göteborg University.

Charness, G., \& Rabin, M. (2002). Understanding social preferences with simple tests. Quarterly Journal of Economics, 117(3), 817-870.

Cook, K. S. \& Cooper, R. M. (2003). Experimental studies of cooperation, trust, and social exchange. In E. Ostrom \& J. Walker (Eds.), Trust and Reciprocity (pp. 209-244). New York: Russell Sage. 
Croson, R. \& Buchan, N. (1999). Gender and culture: International experimental evidence from trust games. American Economic Review, 89(2), 386-391.

Dasgupta, P. (1988). Trust as commodity. In D. Gambetta (Ed.), Trust: Making and Breaking Cooperative Relations (pp.49-72). Oxford: Blackwell.

Eagly, A. H. (1983). Gender and social influence: A social psychological analysis. American Psychologist, 30, 971-981.

Eagly, A. H. \& Johnson, B. T. (1990). Gender and leadership style: A meta-analysis. Psychological Bulletin, 108, 233-256.

Eckel, C. C. \& Grossman, P. J. (1998). Are women less selfish than men? Evidence from dictator experiments. Economic Journal, 108, 726-735.

Eckel, C. C. \& Grossman, P. J. (2001). Chivalry and solidarity in ultimatum games. Economic Inquiry, 39(2), 171-188.

Eckel, C. C. \& Wilson, R. K. (2003). Conditional trust: Sex, race and facial expressions in a trust game. Working paper. Rice University.

Eckel, C. C., \& Wilson, R. K. (in press). Is trust a risky decision? Journal of Economic Behavior \& Organization.

Emerson, R. M. (1962). Power-dependence relations. American Sociological Review, 27(1), 3141.

Fehr, E., Fischbacher, U., Rosenbladt, B. V., Schupp, J., \& Wagner, G. (2002). A nation-wide laboratory. Schmollers Jahrbuch, 122, 519-542.

Fehr, E. \& Schmidt, K. (1999). A theory of fairness, competition, and cooperation. Quarterly Journal of Economics, 114(3), 817-868.

Fehr, E. \& K. Schmidt (2002). Theories of Fairness and Reciprocity -- Evidence and Economic Applications. In: Dewatripont, M., Hansen, L. \& Turnovsky, St. (Eds.), Advances in Economics and Econometrics - 8th World Congress, Econometric Society Monographs. Cambridge: Cambridge University Press.

Frey, B. S., Benz, M., \& Stutzer, A. (2002). Introducing procedural utility: Not only what, but also how matters. Working paper. Institute for Empirical Economic Research, University of Zurich.

Fukuyama, F. (1995). Trust: The social virtues and the creation of prosperity. New York: The Free Press.

Geis, F. L., Brown, V., Jennings, J., \& Corrado-Taylor, D. (1984). Sex vs. status in sexassociated stereotypes. Sex Roles, 11, 771-785.

Glaeser, E. L., Laibson, D. I., Scheinkman, J. A., \& Soutter, C. L. (2000). Measuring trust. Quarterly Journal of Economics, 115(3), 811-846.

Glick, P. \& Fiske, S. T. (1996). The ambivalent sexism inventory: Differentiating hostile and benevolent sexism. Journal of Personality and Social Psychology, 70, 491-512.

Güth, W., Schmittberger, R. \& Schwarze, B. (1982). An experimental analysis of ultimatum bargaining. Journal of Economic Behavior and Organization, 3, 367-388.

Hardin, R. (1993). The street-level epistemology of trust. Politics \& Society, 21, 505-529.

Hardin, R. (2002). Trust and Trustworthiness. New York: Russell Sage Foundation.

Helliwell, J. (2002). How's life? Combining individual and national variables to explain subjective well-being. National Bureau of Economic Research Working Paper \#9065.

Hershey, J. \& Schoemaker, P. (1980). Risk taking and problem context in the domain of losses: An expected utility analysis. Journal of Risk and Insurance, 47(1), 111-132.

Hoffman, C. \& Hurst, N. (1990). Gender stereotypes: Perception or rationalization? Journal of Personality and Social Psychology, 58(2), 197-208.

Hughes, E. C. (1945). Dilemmas and contradictions of status. American Journal of Sociology, 50, 353-354.

Inglehart, (1999). Trust, well-being and democracy. In Warren, M. (Ed.), Democracy and Trust (pp. 88-120). New York and Cambridge: Cambridge University Press. 
Jackman, M. R. (1994). The velvet glove, paternalism and conflict in gender, class, and race relations. Berkeley, CA: University of California Press.

Jianakoplos, N. A. \& Bernasek, A. (1998). Are women more risk averse? Economic Inquiry, 36(4), 620-630.

Jost, J. T. \& Banaji, M. R. (1994). The role of stereotyping in system-justification and the production of false consciousness. British Journal of Social Psychology, 33, 1-27.

Kahneman, D., Knetsch, J., \& Thaler, R (1986). Fairness as constraint on profit seeking: Entitlements in the market. American Economic Review, 76, 728-741.

Kawachi, I., Kennedy, B. P., Lochner, K., \& Prothrow-Smith, D. (1997). Social capital, income inequality and mortality. American Journal of Public Health, 87(9), 1491-1498.

Keltner, D.; Gruenfeld, D.H. \& Anderson, C. (2003). Power, Approach, and Inhibition, Psychological Review, 110(2), 265-284.

Knack S. (2002). Social capital and the quality of government: Evidence from the American states. American Journal of Political Science, 46, 772-785.

Knack, S. \& Keefer, P. (1997). Does social capital have an economic payoff? A cross-country investigation. Quarterly Journal of Economics, 112(4), 1251-1288.

Koehler, J. J. \& Gershoff, A. (2003). Betrayal aversion: When agents of protection become agents of harm. Organizational Behavior and Human Decision Processes, 90, 244-261.

Kramer, R. (1999). Trust and distrust in organizations: Emerging perspectives, enduring questions. Annual Review of Psychology, 50, 569-598.

Kramer, R. M. and Tyler, T. R. (1996). Trust in Organizations. Thousand Oaks: Sage.

Kreps, D. M. (1990). Corporate culture and economic theory. In J. E. Alt \& K. A. Shepsle (Eds.), Perspectives on Positive Political Economy (pp.90-143). Cambridge: Cambridge University Press.

LaPorta, R., Lopez-de-Silanes, F., Shleifer, A., \& Vishny, R. W. (1997). Trust in large organizations. American Economic Review, 87(May), 333-338.

Lind, E. A. \& Tyler, T. (1988). The Social Psychology of Procedural Justice. New York: Plenum Press.

Lips, H. M. (1991). Women, men, and power. Mountain View, CA: Mayfield Publishing.

Loewenstein, G. F., Thompson, L., \& Bazerman, M. (1989). Social utility and decision making in interpersonal contexts. Journal of Personality and Social Psychology, 57(3), 426-441.

Luhmann, N. (1979). Trust: A mechanism for the reduction of social complexity. In Luhmann, N. (Ed.), Trust and Power. New York: Wiley.

Maccoby, E. E. \& Jacklin, C. N. (1974). The psychology of sex differences. Stanford: Stanford University Press.

Mainiero, L. A. (1986). Coping with powerlessness: The relationship of gender and job dependency to empowerment-strategy usage. Administrative Science Quarterly, 31, 633-653.

Malhotra, D. (2004). Trust and reciprocity decisions: The differing perspectives of trustors and trusted parties. Organizational Behavior and Human Decision Processes, 94, 61-73.

Mansbridge, J. (1999). Altruistic trust. In Warren, M.E. (Ed.), Democracy and Trust (pp. 290309). Cambridge: Cambridge University Press.

Mayer, R. C., Davis, J. H., \& Schoorman, F. D. (1995). An integrative model of organizational trust. Academy of Management Review, 20, 709-734.

Meeker, B. F. \& Weitzel-O’Neill, P. A. (1977). Sex roles and interpersonal behavior in taskoriented groups. American Sociological Review, 42, 91-105.

Miller, J.B. (1977). Toward a new psychology of women. Boston: Beacon Press.

Nadler, E. B. \& Morrow, W. R. (1959). Authoritarian attitudes toward women and their correlates. Journal of Social Psychology, 49, 113-123.

Oberholzer-Gee, F., Bohnet, I., \& Frey, B. S. (1997). Fairness and competence in democratic decisions. Public Choice, 91(1), 89-105. 
Pillutla, M. M. and Murnighan, J. K. (1996). Unfairness, anger and spite: Emotional rejections of ultimatum offers. Organizational Behavior and Human Decision Processes, 68, 208-224.

Powell, M. \& Ansic, D. (1997). Gender differences in risk behaviour in financial decisionmaking: An experimental analysis. Journal of Economic Psychology, 18(6), 605-628.

Putnam, R. D. (1993). Making democracy work: Civic traditions in modern Italy. Princeton, NJ: Princeton University Press.

Putnam, R. D. (1995). Bowling alone: America’s declining social capital. Journal of Democracy, 6, 65-78.

Putnam, R. D. (2000). Bowling alone: The collapse and revival of American community. New York: Simon and Schuster.

Rabin, M. (1993). Incorporating fairness into game theory and economics. American Economic Review, 83(5), 1281-1302.

Rahn, W. M., Yoon, K. S., Lipson, S. J., \& Garet, M. S (2002). Geographies of trust: Examining variation in generalized social trust across Knight communities. Washington, DC: American Institutes for Research.

Ridgeway, C. L. \& Berger, J. (1986). Expectations, legitimating, and dominance behavior in task groups. American Sociological Review, 51, 603-617.

Ridgeway, C. L., Berger, J., \& Smith, L.R. (1985). Nonverbal cues and status: An expectation states approach. American Journal of Sociology, 90(5), 955-978.

Rosenfeld, R., Messner, S. F., \& Baumer, E. P. (2001). Social capital and homicide. Social Forces, 80(1), 283-309.

Rotter, J. B. (1980). Interpersonal trust, trustworthiness, and gullibility. American Psychologist, 35(1), 1-7.

Rousseau, D., Sitkin, S., Burt, R., \& Camerer, C. (1998). Not so different after all : A crossdiscipline view of trust. Academy of Management Review, 23, 393-404.

Sampson, E.E. (1975). On justice as equality. Journal of Social Studies, 31(3), 45-64.

Schechter, L. (2003). Traditional trust measurement and the risk confound: An experiment in rural Paraguay. Working paper. University of California at Berkeley.

Schubert, R., Brown, M., Gysler, M., \& Brachinger, H. W. (1999). Financial decision making: Are women really more risk averse? American Economic Review (Papers and Proceedings), 89(2), 381-385.

Siegel, S. \& Castellan, J.N. (1988). Nonparametric statistics for the behavioral sciences. New York: McGraw-Hill.

Siegrist, M., Cvetkovich, G., \& Gutscher, H. (2002). Risk preference predictions and gender stereotypes. Organizational Behavior and Human Decision Processes, 87(1), 91-102.

Slemrod, J. \& Katuscak, P. (2002). Do Trust and Trustworthiness Pay Off? Working Paper 9200. National Bureau of Economic Research.

Smith, T. W. (1997). Factors relating to misanthrophy in American society. Social Science Research, 26, 170-196.

Smith, K., Carroll, S. \& Ashford, S. (1995). Intra- and interorganizational cooperation: Toward a research agenda. Academy of Management Journal, 38, 7-23.

Snijders, C. \& Keren, G. (1998). Determinants of trust. In D. V. Budescu, I. Erev, \& R. Zwick (Eds.). Games and Human Behavior: Essays in Honor of Amnon Rapoport (pp. 355-385). Mahwah, NJ: Lawrence Erlbaum.

Sutter, M. \& Kocher, M. (2003). Age and the development of trust and reciprocity. Working paper. University of Innsbruck.

Swim, J. K. \& Campbell, B. (2003). Sexism: Attitudes, beliefs, and behaviors. In R. Brown \& S. Gaertner (Eds.), Blackwell Handbook of Social Psychology: Intergroup Processes (pp. 218-237). Oxford, UK: Blackwell Publishing.

Von Winterfeldt, D. \& Edwards, W. (1986). Decision Analysis and Behavioral Research. Cambridge: Cambridge University Press. 
World Values Survey (1981, 1990, and 1995 waves). ICPSR Archive, University of Michigan.

Zak, P. \& Knack, S. (2001). Trust and growth. Economic Journal, 111, 207-243. 


\section{Appendix A: Instructions to Decision-Makers in Trust Game (female decision-maker, male second player)}

TG_FM_1_February, 2004

Code Number:

\section{Exercise}

Please read all the way to the bottom of this page where it says "End of Exercise" before making your decision. Your decision will help determine how much money you and another person will earn. You and this person have been randomly matched, and will never learn each other's identities. The only thing you know about this person is that he is male. He also knows you are female.

In this exercise, you have to decide between Options A and B.

- $\quad$ If you choose Option A, you and the other person will each earn \$10 for sure.

- If you choose Option B, your and the other person's earnings will be determined by the other person.

Option B works as follows: the person you have been matched with has to decide between a "green" and a "black" alternative.

- If the person you have been matched with chooses "green,” you and the other person will each earn $\$ 15$.

- If the person you have been matched with chooses “black,” you will earn $\$ 8$ and the other person will earn $\$ 22$.

There are people in this room who might be randomly matched with you. Some of them may choose "green" and some of them may choose "black." The number of people choosing "green" and the number of people choosing "black" add up to the number of people who might be matched with you.

\section{KEY QUESTION: How many people choosing "green” do there have to be for you to pick Option B over Option A?}

(Remember: there are ___ people present who might be matched with you. The number of people choosing "green" and the number of people choosing "black" add up to this number. Any number you write down has to be between 0 and this number.)

\section{YOUR ANSWER: I choose Option B, if at least}

\section{people choose "green."}

Rule:

- If your required number of people choosing "green" is higher than the actual number of people in this room choosing "green," then you and the person with whom you have been randomly matched will get Option A (you will both get \$10).

- If your required number of people choosing "green" is equal to or lower than the actual number of people in this room choosing "green," then you and the person with whom you have been randomly matched will get Option B. Your earnings and the earnings of the other person will be determined by the other person's choice of “green”(you will both get \$15) or “black”(you will get $\$ 8$ and the other person will get \$22) as described above.

After everyone has completed this exercise and the questionnaire, we will inform you of the actual number of people in this room choosing "green."

End of Exercise. 
Appendix B: MAPs by Status Group in the Three Games: means, medians, [N]

\begin{tabular}{|c|c|c|c|}
\hline First Mover & Decision Problem & Risky Dictator Game & Trust Game \\
\hline All & $\mathbf{0 . 4 0}, 0.35,[37]$ & 0.39, 0.40, [57] & 0.46, 0.44, [74] \\
\hline Men & $\mathbf{0 . 4 1}, 0.35,[16]$ & $\mathbf{0 . 3 4}, 0.32,[32]$ & $\mathbf{0 . 4 1}, 0.44,[31]$ \\
\hline Women & 0.39, 0.40, [21] & $\mathbf{0 . 4 7}, 0.50,[25]$ & $\mathbf{0 . 4 9}, 0.50,[43]$ \\
\hline Caucasian & $\mathbf{0 . 4 4}, 0.43,[18]$ & 0.35, 0.34, [35] & 0.46, 0.44, [46] \\
\hline $\begin{array}{l}\text { All Minority (non- } \\
\text { Caucasian) }\end{array}$ & 0.35, 0.30, [18] & 0.46, 0.48, [22] & 0.46, 0.46, [28] \\
\hline Caucasian Men & $\mathbf{0 . 4 5}, 0.38,[8]$ & 0.31, 0.30, [20] & $\mathbf{0 . 4 4}, 0.44,[20]$ \\
\hline Caucasian Women & $\mathbf{0 . 4 4}, 0.45,[10]$ & $\mathbf{0 . 4 0}, 0.40,[15]$ & 0.46, 0.45, [26] \\
\hline Minority Men & 0.37, 0.33, [8] & $\mathbf{0 . 3 8}, 0.37,[12]$ & $\mathbf{0 . 3 4}, 0.33,[11]$ \\
\hline Minority Women & $\mathbf{0 . 3 3}, 0.30,[10]$ & 0.57, 0.61, [10] & $\mathbf{0 . 5 4}, 0.55,[17]$ \\
\hline Ages 31-59 & $\mathbf{0 . 4 5}, 0.45,[6]$ & 0.20, 0.10, [5] & $\mathbf{0 . 4 4}, 0.46,[10]$ \\
\hline Ages 18-30 & $\mathbf{0 . 3 9}, 0.35,[30]$ & $\mathbf{0 . 4 1}, 0.40,[52]$ & 0.46, $0.44,[64]$ \\
\hline Ages 31-59 Men & $\mathbf{0 . 5 4}, 0.54,[2]$ & $\mathbf{0 . 2 0}, 0.10,[5]$ & 0.41, 0.44, [5] \\
\hline $\begin{array}{l}\text { Ages 31-59 } \\
\text { Women }\end{array}$ & $\mathbf{0 . 4 0}, 0.45,[4]$ & [0] & 0.47, 0.50, [5] \\
\hline Ages 18-30 Men & 0.40, 0.34, [13] & 0.36, 0.34, [27] & $\mathbf{0 . 4 1}, 0.42,[26]$ \\
\hline $\begin{array}{l}\text { Ages 18-30 } \\
\text { Women }\end{array}$ & $\mathbf{0 . 3 9}, 0.35,[17]$ & $\mathbf{0 . 4 7}, 0.50,[25]$ & $\mathbf{0 . 5 0}, 0.50,[38]$ \\
\hline Protestants & $\mathbf{0 . 4 4}, 0.45,[6]$ & 0.31, 0.33, [15] & $\mathbf{0 . 4 5}, 0.45,[20]$ \\
\hline Non-Protestants & 0.39, 0.35, [31] & $\mathbf{0 . 4 2}, 0.40,[42]$ & 0.46, 0.45, [54] \\
\hline Protestant Men & $\mathbf{0 . 5 0}, 0.50,[3]$ & 0.26, 0.29, [11] & $\mathbf{0 . 4 5}, 0.45,[12]$ \\
\hline Protestant Women & $\mathbf{0 . 3 7}, 0.35,[3]$ & $\mathbf{0 . 4 5}, 0.45,[4]$ & 0.46, $0.45,[8]$ \\
\hline $\begin{array}{l}\text { Non-Protestant } \\
\text { Men }\end{array}$ & $\mathbf{0 . 3 9}, 0.34,[13]$ & $\mathbf{0 . 3 7}, 0.40,[21]$ & $\mathbf{0 . 3 8}, 0.33,[19]$ \\
\hline $\begin{array}{l}\text { Non-Protestant } \\
\text { Women }\end{array}$ & 0.39, 0.43, [18] & $\mathbf{0 . 4 7}, 0.50,[21]$ & $\mathbf{0 . 5 0}, 0.50,[35]$ \\
\hline
\end{tabular}

